\title{
Critique of French Colonialism in Poem Neigesur Paris (1945)by Léopold Sedar Senghor
}

\author{
Azkiya Nisa ${ }^{1}$ and Diah Kartini Lasman ${ }^{2}$ \\ ${ }^{12}$ Faculty of Humanity, Universitas Indonesia, Depok, Indonesia \\ 1azkiya.nisa@ui.ac.id; ${ }^{2}$ deka.lasman@gmail.com
}

\begin{abstract}
French colonialism is one of the important issues in African history. Léopold Sedar Senghor, the founder of the Négritude movement, expressed resistance through his works, one of which was the poem, Neigesur Paris(1945), against slavery, oppression, and inferiority carried out by the French.This article discusses criticism of French colonialism in the poem Neigesur Paris(1945) by Léopold Sedar Senghor. This research is a qualitative study using a postcolonial approach with Sub-altern theory written by GayatriSpivak, Négritude by Léopold Sédar Senghor, and also a structural approach.The findings of this article are criticism towards the construction of French civilization in the postwar period. The critique states that the pardon expressed by the Poet against the French people for the practice of colonization is a weapon to attack back France and show pride of the African identity that is presented through depictions of nature and African tribes.
\end{abstract}

Keywords: post-colonialism, subaltern, négritude, civilization

\section{INTRODUCTION}

An important problem in African history is the invasion and colonization by France for about five hundred years. French colonialism had a profound influence on Senegalese literature. Senegalese literature, which was originally dominated by stories of native African traditions, was later influenced by French writings that gave Western ideas. The question of colonial authority also began to emerge and became a forerunner to the opposition to colonialism. Senegalese literature which has gained Western influence is expressed through Francité and Négritude as forming the perception of the life of the African people to all French speakers[1]. Besides, the concept of Négritude is also part of Senegalese literature. The term Négritude comes from the term 'negro' which refers to black people[2]. Négritude is a political and literary movement that emerged from the $1930 \mathrm{~s}$ to the $1950 \mathrm{~s}$, starting between Frenchspeaking African and Caribbean writers and living in Paris in protest against French colonial rule and assimilationist policies. The movement was influenced by the Harlem Renaissance, a writer who emerged among a group of black thinkers and writers, especially poets and novelists, in the United States in the 1920s. Literature with the theme Négritude is dominated by the collective awareness of black writers as members of minority groups under other groups who are stronger in the political and social order[3]. Negritude's literary themes are symbols of alienation, rebellion, and independence. The founders of the Négritude movement were Léon Gotran-Damas, AiméCésaire, and the main founder, Léopold Sedar Senghor. 
Senghor is a poet, writer, and statesman who was born in the city of Joal, Senegal. The characteristics of the Négritude that Senghor put forward are a defence of African culture and the idea of universal civilization. Senghor describes the quality of Africa that is often mocked by the Western people. The intuitive reason of Africans is the main focus and characteristic of his writings. Senghor has many works in the form of essays, anthology, and poetry[4]. The poem that will be discussed in the research is Neigesur Paris (1945), originating from the collection of poetry Chants d'ombre (1945) which many describe the Poet's feelings towards France[5].

The poemNeigesur Paris (1945) has previously been discussed by BabacarM'Baye in a study entitled Anticolonialismdans le poème de Léopold Sédar Senghor Pendant La Guerre. In the study, the poems Neigesur Paris (1945) and Prière aux Masques(1945) revealed the dualism between the elements of cosmopolitanism and anti-colonialism. [6] Other research that discusses Senghor's poem was written by NawelBounaghla (2003) in a dissertation Images of Cultural Values in Sédar Senghor's Poem "Prayer to the Masks". The dissertation highlights the cultural values of the emerging African concept, namely African nationalism and cultural ambivalence. Thesis entitled The Figure of a Woman in the poem "Femme Noire" by Léopold Sedar Senghor by NatasiaDilla also discusses the meaning of a poem by Senghor that has shown the worship and pride of poets towards black women in Africa and the continent of Africa as the birthplace of the poet[7]. The last two studies raised a strong African identity[8].

\section{METHOD}

The method used is a qualitative method with a structural approach to describe the interrelationships and functions of each element of poetry, namely metrics, syntax, semantics, and pragmatics as structural unity that together produce the whole meaning. This research also uses a postcolonial approach with the subaltern theory written by GayatriSpivak and Négritudeby Léopold Sédar Senghor to understand the critique of the exploitation of African society and France's construction conveyed through this poem.

\section{RESULT AND DISCUSSION}

\subsection{Text Structure of La Neigesur Paris (1945)}

Neigesur Paris (1945) by Léopold Sédar Senghor consists of 3 stanzas which include 26 lines. The dominant form of poetic stanza is printed with three lines and the first stanza has a dominant number of lines. The distribution of syllables in the poem is uneven and each array has a different number of syllables. In total, the poem consists of 8 sentences that end with a dot. Spread of dots that indicate the end of a sentence is not evenly distributed. The rhymes of the three stanzas in the poem are also irregular and different.

The free elements in the poem Neigesur Paris (1945) can signify a desire to achieve freedom. The large difference in the rhyme and number of syllables in the poem illustrates the theme of dominance that the author wishes to convey. The form of the last two stanzas, Tercet, signifies a dynamic nature and a change. The concepts of change and dynamics are also supported structurally by the irregular distribution of syllables in this poem.

The first part is a description of the condition of France which worsened during the war. There is a confrontation of the situation with the poet who is fighting for France as a metropolis. This shows a paradox because the situation requires the poet to defend democracy 
and freedom deprived of his fellow countrymen. Thus, the first part describes the poet's satirical response to France in wartime. The second part of the poem is a description of hatred towards the practice of French colonization. The colonial practices include slavery or human trafficking by state actors. This part also then describes the feeling of the poet that is compared by the snow in the sun. The third part is a feeling transformation which is illustrated through the shifting seasons. In addition, the section also explained the character reconciliation through forgiveness to France.

Recipients (P2) have the appellation "Seigneur" which is a call of honor to the great people in the previous regime. Looking at the background of poets who are African and have felt under French colonialism, poetry can be concluded directed to the French people. Besides the French, "Seigneur" is also a call to God that is often used in the scriptures. Thus, the speaker (P1) is the poet and the recipient (P2) in the poem is French or God. Both the French and God are two concepts that share a field of meaning as a ruler.

\subsection{The Condition of Africans as Subaltern}

According to Spivak (1994), Subaltern is a term used to mention subordination in a society that is classified through class, caste, gender, race, age, and other forms of marginalization. The main problem with subalterns is not only about the categories of oppressed people or the oppressed working class, but also about anyone whose voice is limited by an access that represents them. Spivak's focus is the philosophical, cultural, political, economic legacy of European colonialism towards the people they colonized[9].

Subaltern in the poem Neigesur Paris (1945) is African people. The colonial era made white French people become the ruler and majority of Africans in France. They practice colonization that is destructive to Africans. The position of the Africans is subalternwho is dealing with the French and treated differently. The main problem of Africans as subalternin poetry is its limited voice. Poetry became a tool of struggle to show the voice of Africans as a subaltern in fighting colonial oppression. Poets represent Africans who have no freedom of voice by attacking and condemning the practice of colonization through poetry.

The position of the Africans as a subaltern is shown by the Poet through the power of the French as a metaphorical "leurs canine longue" (line 21) which means their long fangs. The authorities who are often called "diplomats" (line 21) in poetry are depicted not as human beings, but as wild animals. The African population is described as "la chair noire"(line 22) or prey. The depiction shows that Africans are not seen by the French as complete human beings but only prey who are ready to be poached and ready to be mortgaged. The depiction of France as an animal has the significance that the actions taken by France against Africa are inhumane and show the condition of Africa as an alienated subaltern.

Africans as a subject of repression are proven by the position of the French as the ruler of the Africans. This is shown through the repetition of the word "les mains blanches" (line 13) or "white hands". The word appears in the second part of the poem and is mentioned three times. This proves the dominance of the French people over Africa. The use of the synecdoche "white hand" symbolizes the body parts of white people who commit acts of violence against Africans, such as the slaughter of indigenous blacks, trade, slavery, and the destruction of natural resources. The quantity of "white hands" is described in the plural form which describes the level of cruelty of the practice of colonization. The improper treatment shown 
through the verbs "flagllèrent"(line 14) and "gifler"(line 15) which is sequenced after the word "les mains blanches" has the meaning of "whipping" and "slapping" Africans.

Colonialism put strong mental pressure on Africans. Their minds are completely squeezed out by the act of direct oppression. The poet's statement about the silence and hatred of Africans in poetry shows the occurrence of mental degradation and the arising of inner upheaval in their lives as subaltern, as the result of being filled with experiences that suppress their feeling.

\subsection{Condemnation of Post-War French InfrastructureConstruction}

Négritude as a political movement has a close relationship with African nationalism, a theme that often appears in Senghor's writings. Three important elements of African nationalism are Unity, Independence, and Equality. The element of Unity is based on the success of reaching the end of shared colonialism. Independence is expressed in freedom and the right to self-determination and decision which refers to the recognition of state sovereignty. The Equality element requires equal treatment of large or small, weak or strong nations at the international level[10].

At the end of the war, all warring countries faced the consequences caused by the conflict, including France because the majority of the war took place on French territory. The capital of France, Paris, in poetry is described as a city that was destroyed after the Second World War. Many major roads were bombed and the transportation system was damaged. Inflation is streaking and the economy is very unstable. France then needed human resources to rebuild a civilization destroyed by war. After the ceasefire ended, France entered the reconstruction process. Due to lack of resources, France exploited people who came from its colonies and were brought to France to rebuild their countries. In addition, several colonies gained French citizenship.

"Elles"(line 19) refers to "les mains blanches"(line 13)which was mentioned in the previous subtitle and can be thought as meaning of French people. The use of African labor is one form of exploitation from the practice of colonization by the French. The exploitation referred to in poetry is the exploitation of human resources for the benefit of French construction through slavery. The poem also shows that the white color associated with the French people is a symbol of crime, violence, and instability. Conversely, the color of black in poem is associated with Africans that is symbolizing life and balance. The conclusion is that the meaning of each line of poetry constitute critical and deconstructive responses on colonialism and the effects of human humiliation and crimes committed by Europeans.

Critique of French colonialism is supported by the awareness of African identity that arises through the portrayal of one of the African tribes, namely "Saras" (line 18) and the typical tree of Africa, namely "rôniers"(line 18). "Saras" is a group of people who live in the southern suburbs of Sudan, especially in the northwestern region of the Central African Republic and the south-central region around the southern Lake of Chad, while "rôniers" are Senegal typical tree. "Rôniers" placed right in the heart of the African forest indicate that the tree is the heart of Africa or the giver of life which, if cut down, indicates that African life has been taken.

France has exploited Africa's most important natural resource, the African forest. According to the perception of Africans, the forest is a link between heaven and earth or 
symbolizes the relationship between the spiritual world of ancestors and humans. Rituals and ceremonies that use forest symbols often function to connect people with the cultural heritage and past of their ancestors. Deforestation is the same as cutting off connections between Africans and their ancestors[11]. Thus, the exploitation of forests as a cultural symbol that has been passed down from generation to generation has a significance relation to the destruction of identity from Africa. The important position of African forests is supported by the statement "centrel'Afrique" (line 17) or "in the middle of Africa" which describes forests as the source of all life.

After the World War ended, France realized that the system of colonialism would not last forever. France then promised to give independence to its colonies, even though they were not ready to do so. Therefore, France granted citizenship to the people of its colonies and placed them in Paris as a metropolitan city built by the French. This then became an irony because Africans who had been sent to France to build civilizations destroyed by the war still had a hatred for colonialism carried out by France[12]. On the one hand, Africa feels acknowledged, but on the other hand still has a deep sense of revenge.

The poem Neigesur Paris (1945) is a critique that the built of civilization cannot be based on hatred. Forgiveness becomes indispensable for creating universal civilization. Critique is also conveyed in poetry through a description of granting citizenship by the French that is not sincere. The services of Africans who had helped to build French civilization were granted French citizenship, but were not treated as fellow countrymen. Thus, it can be said that poetry provides critique of France which overrides the human side in order to build a civilization destroyed by war. In poetry, critique was also conveyed to France that building civilization is not only concerned on infrastructure development, but it must prioritize humanity. If it related to the concept of African nationalism, the granting of citizenship, exploitation of human and natural resources to build French civilization is one the imperialism and colonialism systems which hinders the formation of African nationalism. In poetry, three elements of African nationalism which contain elements of unity, freedom, and equality are dreams that African people want to achieve.

\subsection{Pardonas a Form of Reconciliation}

The meaning of the poem Neigesur Paris (1945) has described the city of Paris with poor conditions due to war. The statement "le froid incorruptible" (line 3) in poetry which means "eternal cold" can be interpreted as "eternal snow". The term describes a hope for peace and purification of a city ravaged by war. In poetry, the image of snow handed down by "Seigneur"(line 1) or God on the day of his birth is a purification form of damage, in the context of Christianity referred as Christmas Day. Purification was shown for France whose territory was used as a battleground.

The poem shows prayers directed to Christ. The previous subtitle explains that this poem condemned France for the practice of colonization. Despite all the misery that arises from the practice of colonization, the resolution chosen by the poet is the will of peace. This is shown through "la mort blanche"(line 14) or "white death" which refers to the Bible that Christ defeated or destroyed death by dying on the cross. The Romans 6:23 verse in the Bible says that "the wages paid by sin is death" which refers to Jesus sacrifice to suffer in order to atone for the sins of men. If related to poetry, the suffering experienced by poets and the death of Africans due to war is a sign of the rise and glory of the African nation. 
"Drapsblancs" (line 6) show the exclamation of peace. It can also signify a war that has ended. The poet through his poetry forgives as a form of reconciliation and acceptance of others. The poet chose not to hate France for the colonialism he had committed. This then becomes an irony because the African nation which is often called barbaric nation, fights it by teaching fraternity and forgiveness towards offense. This is proven by the following quote:

\section{"Seigneur, j'aiacceptévotrefroidblanc qui brûle plus que le sel"}

("Lord, I accepted your cold white burning more than salt")

"Froidblanc" is a synecdoche for snow. Meanwhile, snow is a metaphor for peace. Thus, "accepter froidblanc" can have the meaning of accepting the peace proposed by Jesus through falling snow on the day of his birth. The statement at the end of the poem shows that the poet reconciled with the French people, behind the inner turmoil caused by French colonialism at the beginning of the poem. The statement "J'oublie"(line 12) on the previous line which means "I forgot" increasingly shows that the Poet's peaceful will is a form of resistance through his awareness of history and his identity as a French colony. This awareness is in accordance with Senghor's Nègritude concept that black people must be aware of their race even in the place of mixing culture between black and white people.

Meanwhile, "le sel" in the poem shows the 'meaning of salt and light of the world' in the Bible. According to Matthew 5: 13-16, salt has a very important function and role, especially in making a dish. These functions include preserving food, binding spices, and supplementing nutritional content. Food will be tasteless and will only highlight one flavor of seasoning without salt. The poet applies the concept in poetry to a useful role so that it can become 'the salt of the earth'. The meaning of light in salt means Jesus himself. Humans are expected to imitate Jesus attitudes and apply to the surroundings, such as forgiveness or pardon.

In contrast to Cèsaire, the concept of Négritude Senghor distinguishes European values from the values of the African world. Senghor states that Négritude is a belief in African values and an authentic black self-formation. Black men's culture must be recognized not only as a matter of human justice, but because the values of Négritude can be instrumental in the reintegration of the positive values of western civilization and the reorientation of contemporary humans towards a better life[13]. This is in accordance with the peace proposed by the poet in poetry over colonialism carried out by the French. Poetry shows Africa is a civilized nation and condemns the act of colonialism or other crimes. The concept of peace or forgiveness raised by poets in poetry can be a weapon to attack French people who previously thought that Africans were not civilized.

Previous research more dominantly discusses poetry related to anti-colonialism and cosmopolitism in France, whereas research that raised poetry contains criticism of the exploitation of African society and development in France has never been done deeply [14]. Therefore, this article elaborate further on the criticism of the development of France through the poem Neigesur Paris(1945). In addition, the article also uses the Subaltern theory by GayatriSpivak and a structural approach that has never been done before. A different finding from the article is the strength of Africa nation which is shown through forgiveness or pardon. 


\section{CONCLUSION}

The poem Neigesur Paris (1945) by Leopold Sedar Senghor is a modern poem that does not follow the conventional poetry rules. The poem shows the counter position between the French as the superior subject and Africans as the inferior subject. The French have treated Africans unfairly and made them subalterns. Poetry also illustrates the destructive effects of the practice of colonization that can degrade and damage the identity of the African nation. The findings of this study are criticisms of the construction of postwar French civilization. Civilization should not only be limited to infrastructure development but humanitarian development. African participation in the development of France hindered the formation of African nationalism which included three elements, namely unity, freedom, and equality. The peace or pardon proposed by the poet in poetry is a form of resistance carried out in the form of reconciliation to show the strength and noble attitude of a civilized nation. The forgiveness revealed by the Poet against the French people for the practice of colonization is a weapon to attack France and show pride in the African identity that is presented through the depiction of the appearance of nature and African tribes.

\section{REFERENCES}

[1]. T. D. Warner. The Limits of the Literary: Senegalese Writers between French, Wolof and World Literature.ProQuest Dissertations Publishing, 2012.

[2]. D. Murphy. "Birth of a Nation? The Origins of Senegalese Literature in French", hgbResearch in African Literatures, Vol. 39, No. 1, pp. 48-69, 2008.

[3]. B. Galafa. "Negritude in Anti-colonial African Literature Discourse", The Journal of Pan African Studies, Vol. 12, No. 4, pp. 287-298, 2018.

[4]. A. Afolayan. "AbiolaIrele and the Context of African Philosophy Discourse", Research in African Literatures, Vol. 49, No. 4, pp. 1-19, 2018

[5]. I. A. Singare. L'oeuvrepoétique de Léopold SédarSenghor :esthétique de la reception, procès de la création. Linguistique.Université de CergyPontoise, 2012.

[6]. B. M'Baye. Cosmopolitismeetanticolonialismedansquelquespoèmes de Léopold Sédar Senghor pendant la Seconde Guerre mondiale. Migrance, 2003.

[7]. D. Natasia. SosokAfrikadalamPuisi Femme Noire karya Léopold Sédar Senghor.Universitas Indonesia, 2010.

[8]. N. Bounaghla. Images of Cultural Values in Sédar Senghor's Poem "Prayer to the Masks".UnivesitasAbou-BekrBelkaid, 2016.

[9]. G.C. Spivak. Can the subaltern speak?.Columbia University Press, 1994.

[10]. I.G. Shivji. "The Rise, The Fall, and The Insurrection of Nationalism in Africa.", 2004.

[11]. G. Calame-Griaule. Le Thème de l'arbredans Les ContesAfricains.SELAF, 1969-1970.

[12]. F. Cooper. Citizenship between Empire and Nation: remaking France and French Africa, 1945-1960. Princeton University Press, 2014.

[13].Y. C. Ripert, "Rethinking Négritude: AiméCésaire\& Léopold Sédar Senghor and the Imagination of a Global Postcoloniality." Order No. 10284686, Columbia University, Ann Arbor, 2017.

[14] K. Saddhono and S. Supeni. "The role of dutch colonialism in the political life of Mataram dynasty: A case study of the manuscript of Babad Tanah Jawi." Asian Soc. Sci. vol. 10 no.15 pp. 1-7, 2014 